Received 24 June 2020; accepted 16 December 2021. Available online 9 January 2021

\title{
The Characteristics of Livable Streets: A Study of Physical Aspects of two Streets in Riyadh
}

\author{
Ahmed M. Abdulmughni ${ }^{1}$, Waleed S. Alzamil ${ }^{2}$, \& Abdullah M. Alabed ${ }^{3}$ \\ ${ }^{1}$ Master of Science in Urban Design, King Saud University, Riyadh, Kingdom of Saudi Arabia. \\ 2 Associate Professor, Department of Urban Planning, King Saud University, Riyadh, Kingdom of \\ Saudi Arabia. \\ ${ }^{3}$ Professor, Department of Urban Planning, King Saud University, Riyadh, Kingdom of Saudi Arabia \\ Correspondence1amughni22@gmail.com, ${ }^{2}$ waalzamil@ksu.edu.sa, ${ }^{3}$ amalabed@ksu.edu.sa,
}

\begin{abstract}
Riyadh is one of the major capital cities of the world, its urban fabric has been affected by rapid urbanization and population growth. Enormous urban expansion has had negative effects on the human dimension, as the streets became more devoted to transportation rather than an integrated urban space. The local municipalities in Riyadh have exerted efforts to restore the human dimension to streets by developing urban spaces and built environments. However, these efforts did not provide a strategy for creating livable streets, because they were built based on individual initiatives. This work aims to investigate the physical aspects of Riyadh streetscapes and define their influences on the livability and quality of spaces. This paper provides a descriptive analysis of two streets in Riyadh, Tahlia Street and Tabuk Street, which have been developed to make them pedestrian friendly. The research data were obtained through field surveys, interviews, and observations. Moreover, in-depth analyses of several government reports from The Royal Commission for Riyadh City and the Ministry of Municipal and Rural Affairs were conducted. Results show that Tahlia Street has wide physical aspects compared to Tabuk Street, making the former more vital than the latter. However, both streets lack some street infrastructure to protect pedestrians from weather conditions. Finally, the paper proposes to develop the current conditions of the physical characteristics of street scenes in order to improve the quality of the streets in Riyadh and enhance the residents' quality of life.
\end{abstract}

\section{Keywords:}

Livable, streets, physical, urban design, quality of life, Riyadh, Saudi Arabia

$$
\text { خصائص الثوارع الحيوية: دراسة الجوانب المادية لثدارعين في الرياض }
$$

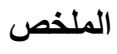

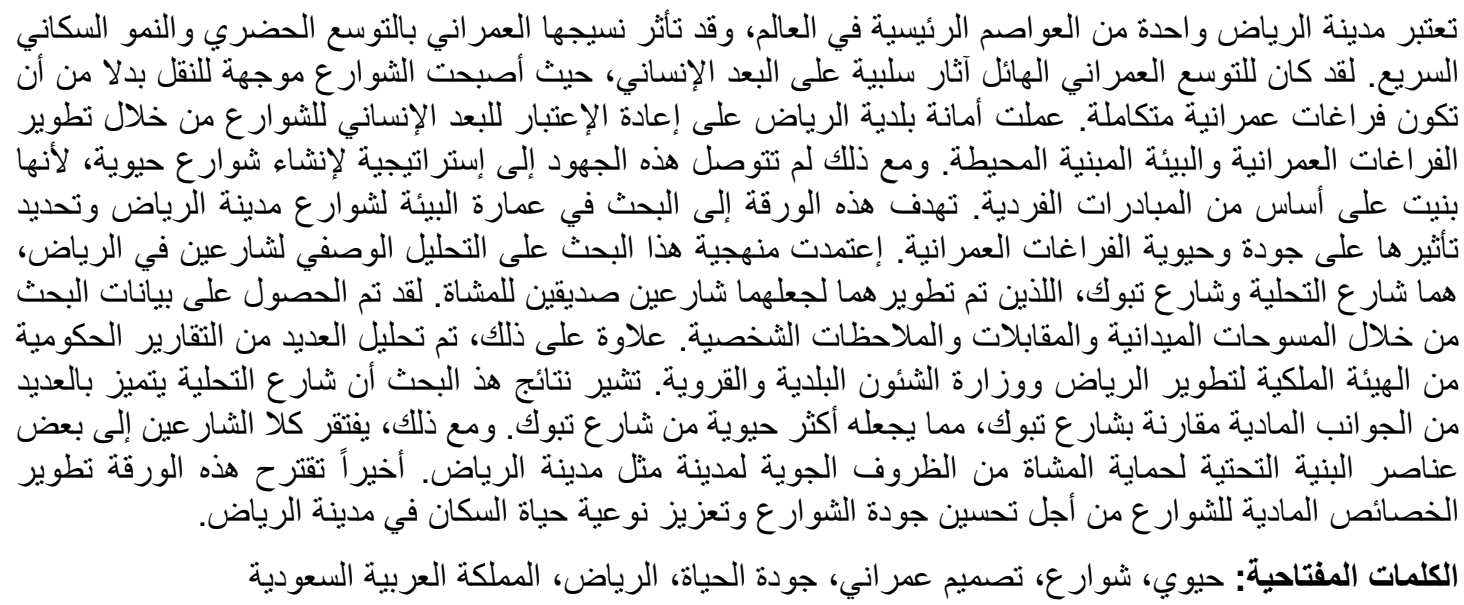




\section{INTRODUCTION}

Urban spaces have dominant characteristics, such as the quality of the urban elements and activities in which they take place. These qualities consolidate the sense of urban space (Mahmoudi et al., 2015; Speiregen, 1965). Urban spaces, as an integral part of the city's spatial structure, consist of two basic formats: the square and the street (Krier, 1979), and their functions distinguish these spaces from each other (Amin, 2008). The street plays a crucial role in constituting the life of the society and is essential in defining the cultural, social, economic and political functions of city. It is the first distinctive element that determines the character of a place (Ahmed, 2019). Many current studies have confirmed that social and physical problems have led to the deteriorating livability of the built environment. Studies have shown that most social problems emerge from the related physical problems (Hedman \& Jaszewski, 1984; Mitchell, 2003; Low \& Smith, 2006). In relation to this, the concept of livable streets involves improving the urban environment, the right of pedestrians, and safety levels in their respective areas (Appleyard, 1980)

In some countries, urban streets have been struggling for decades due to a wide range of problems. Although great amounts of money are spent annually on road construction and maintenance, there remains a lack of noticeable interest in creating attractive places for public life. Public life in the streets is an overlooked topic in the field of urban planning, as most studies have focused on how to accommodate vehicles (Safdie, 2018). As the streets became dedicated to servicing vehicles, this has affected the residents' ability to socialize with one another (Appleyard \& Douglass, 2017). Researchers have pointed out that streets exemplify an important part of public spaces and are apparent as a public realm (Mehta, 2007; Jacobs, 1961; Appleyard, 1981). Jacobs (1961) and Appleyard (1981) were the first to establish the concept of "livability" in the late 1960s. They endeavored to improve and humanize the open spaces of modern cities by applying such a concept. They also highlighted the idea of livability, especially in the streets, as a fundamental aim to obtain a good urban environment (Mahmoudi et al., 2015; Madanipour et al., 1998; Soja, 1989; Davis, 1990).

Riyadh has grown from a small city with an organic layout to a megacity characterized by uncontrolled urban sprawl. In fact, one study has described Riyadh City as having unrestrained urban sprawl, rapid population growth, and universal dependence on automobile travel for all journeys (Al-Mosaind, 2018). Urban expansion was affected by the economic boom in 1970, during which new residential neighborhoods emerged to accommodate population growth (Alzamil, 2016). Doxiadis implemented its first Master Plan in the early 1970s. This Plan was built around the goals of accommodating the rapid rise in car traffic and horizontal expansion to absorb population growth (Al-Hathloul, 2017). The Plan was later placed to encourage only the automobile users, and other modes of travel, like walking and cycling, were not considered. As a result, the number of car users increased, directly and indirectly leading to many problems, such as traffic congestion, traffic accidents, poor conditions for pedestrians and cyclists, poor social relationships, and high levels of obesity. Urban design indicators are still below standard, where per capita green space does not exceed 0.9 square meters. Furthermore, the number of steps a person walks is less than 3,800 steps per day, which helped increase obesity rates (Quality of Life Program, 2017).

As a result of the significant deterioration of the built environment, the City has undergone a program called "Humanizing the City" in order to recreate a livable 
cityscape (Bin Ayyaf, 2015). Many streets were developed by amending or constructing new sidewalks throughout the city and adding street elements, such as trees, benches, and plinths. These attempts were implemented to encourage walking and to create livable streets. However, these attempts were fragmented, random, and did not have an associated network. In short, these attempts were just limited to expanding the platform and adding some elements to the street. Yet, comprehensibly improving the built environment and creating livable streets require an integrated and not dispersed treatment. Therefore, the Council of Economic Affairs and Development identified a series of 12 programs to achieve the 2030 Vision. The Quality of Life 2020 Program focuses on making Saudi Arabian a highly livable city by developing the people's lifestyle and improving their quality of life (Quality of Life Program, 2017).

The current paper focuses on understanding the characteristics of livable streets by analyzing the case studies of two streets in Riyadh. Improving the urban environment in the streets is an important entry point in achieving the quality of life. The results of this paper can help improve current urban conditions in the streets and make them livable within the framework of Vision 2030.

\section{RESEARCH PROBLEM}

Riyadh City has witnessed significant urban growth during the past three decades as a result of urbanization and population growth. Riyadh's population increased from $1,389,500$ people in 1987 to $6,506,700$ people in 2017 . The urban growth in Riyadh is characterized by horizontal spread, with the urban densities concentrated on the main roads (Royal Commission for Riyadh City, 2014). The total urban development area in Riyadh is $3,115 \mathrm{~km}^{2}$, and the planned land area until 2017 is $1820 \mathrm{~km}^{2}$, comprising $58 \%$ of the urban development area (Royal Commission for Riyadh City, 2018). Thus, the horizontal expansion of Riyadh has contributed to the dominance of vehicles over other means of transportation. Moreover, the streets became devoted to servicing vehicles and lost their function as livable streets.

\section{RESEARCH OBJECTIVES}

The purpose of this paper is to investigate the physical aspects of Riyadh's streetscapes and define their influences on the livability and quality of spaces. The paper also aims to determine whether the physical aspects of streetscapes can affect the livability of Riyadh's streets. To accomplish these aims, three issues will be discussed as follows:

i. The physical aspects that affect the livability and quality of streetscapes;

ii. The existing circumstances of the distinguishing physical characteristics of Riyadh's streetscapes; and

iii. The effective strategies to address the physical problems in order to promote the livability and quality of Riyadh's streets.

\section{LITERATURE REVIEW}

\subsection{Livable Streets}

The livability concept can be traced back to the latter decade of the 20th century (Appleyard, 1981; Jacobs \& Appleyard, 1987; Davis, 1990; Bosselmann et al., 1999). The concept of "livability" includes many planning contexts, such as transportation, community development, and quality of life. Researchers at that time have criticized 
the various problematic features of urban spaces, such as noisy, substandard quality, and polluted environments. Jacobs and Appleyard (1987) emphasized the concept of livability as one of the objectives of obtaining a high quality and livable urban environment. Their main goal was to optimize the quality of urban spaces in the modern cities (Bandar \& Shahcheraghi, 2012). The principles of livability focus on providing multiple transportation options, affordable housing, economic competitiveness, community development, alignment of local policies, and upgrading the residential environment (Herrman \& Lewis, 2017).

Appleyard discovered the negative effects of traffic noise and speed on the quality drop of residents' quality of life (Appleyard \& Lintell, 1972). Livable streets were discussed by Appleyard in his book published in the early 1980s. He applied traffic calming techniques in numerous cities of the world to create more humanized urban environments in relation to the continued growth of traffic volume. Appleyard defined livable streets as those that place more concern and focus on pedestrians and cyclists compared with traditional urban streets, thus resulting in such streets being used equally by everyone. However, the concept of livable streets is not just limited to providing a safe and pedestrian-friendly environment. The concept of viable streets also includes creating an urban environment that supports human interaction with the environment in a manner that facilitates mental, psychological, and physical development (Appleyard B. , 2017). The livable streets consist of the following principles:

- Streets as a safe space

- Streets as a healthy and livable environment

- Streets as a community

- Streets as a friendly territory

- Streets as a place for learn and play

- Streets as green spaces

- Streets as a unique historic place

After Appleyard's studies, several works investigated street uses and street life from diverse perspectives. For example, Bosselmann et al. (1999) examined the street livability by comparing livable streets with traditional ones. Dumbaugh and Gattis (2005) studied the level of safety in streets. Mesbahul Tariq (2007) showed the effects of traffic on users' choice of commute mode on Morden City and demonstrated the effects of traffic calming on walkable streets and connection encouragement. Sauterand Huettenmoser (2008) examined traffic management and presented the great potential of having a good quality social life by having peaceful streets. Layne (2009) clarified how landscapes are developed for public spaces and reported that environmental factors can bolster interactions between different communities. Tilaki et al. (2014) exhibited how friendly environmental designs can boost the livability of cities and revealed the considerable effect of the physical elements on the users' sense of space and apperception of distinguished identities. Vuchic (2017) discussed the consequences of immoderate automobile dependence and concluded that the most livable cities have an intermodal system that balance highway and public transit modes while also providing for pedestrians and bicyclists. He also defined the policies necessary for realizing livable cities. Whitney et al. (2020) discussed that livable streets are part of a competitive city economic development strategy of appropriating convenience into a planning system that promotes neighborhoods with the extreme economic potential.

The reviewed studies above are based on worthy assessments of livable streets from various viewpoints. Yet, each and every one of these studies only examined some of 
the effective factors of livable streets and quality, assuming that all other physical aspects are identical. In order to fill this gap in the literature, this study seeks to identify the physical aspects that influence the livability and quality of streetscapes. Consequently, the scope of this research is limited to the physical aspects, while the concept of livability aims to provide a better understanding of the diverse social and functional aspects of urban spaces.

\subsection{Physical Aspects of Streetscapes}

The physical aspects that influence the design and livability of streets were selected by studying the published works between 1975 and 2018. As presented in Table 1, the reviewed references were designated among the distinguished and widely quoted urban space studies. As the literature has not yet matured on the same aspects, the current research classified and combined the most important studied aspects of livable streets. The chosen aspects of this framework were the most commonly mentioned aspects by several references, as presented in Table 1. Depending on the literature, some aspects (street segment length, retail facade, number of doors on the street, street greenery, and facilities for disabled) that were not studied extensively were also included in this study as insights for future works. The relevant studies are listed in Column II of Table 1. Finally, 10 aspects each with four levels were designated to represent the micro streetscale built environment for walking.

Table (1). The Physical Characteristics of Livable Streets

\begin{tabular}{|c|c|c|c|}
\hline Aspects & Related literature & Description & Levels \\
\hline $\begin{array}{l}\text { Street segment } \\
\text { length }\end{array}$ & $\begin{array}{l}\text { Dijkstra and Timmermans, } \\
\text { 2002; } \\
\text { Zhu and Timmermans, } 2011\end{array}$ & $\begin{array}{l}\text { The length of one street } \\
\text { segment from one intersection } \\
\text { to the next intersection }\end{array}$ & $\begin{array}{l}4=\text { Shorter than } 100 \mathrm{~m} \\
3=100 \mathrm{~m} \text { to } 200 \mathrm{~m} \\
3=200 \mathrm{~m} \text { to } 300 \mathrm{~m} \\
1=\text { More than } 300 \mathrm{~m}\end{array}$ \\
\hline $\begin{array}{l}\text { Retail shops in } \\
\text { the facade of } \\
\text { streets }\end{array}$ & $\begin{array}{l}\text { Dijkstra and Timmermans, } \\
2002 \text {; Kurose et al., 2009; } \\
\text { Zhu and Timmermans, 2011; } \\
\text { Guo and Loo, 2013; } \\
\text { Borgers and Timmermans, } \\
2015\end{array}$ & $\begin{array}{l}\text { The proportion of the street } \\
\text { front occupied by retail shops }\end{array}$ & $\begin{array}{l}4=100 \% \text { of retail shops } \\
3=50 \% \text { of retail shops } \\
2=25 \% \text { of retail shops } \\
1=\text { No retail shops }\end{array}$ \\
\hline $\begin{array}{l}\text { The average } \\
\text { number of doors } \\
\text { on the street }\end{array}$ & $\begin{array}{l}\text { Gehl, 2013; } \\
\text { Alfonzo et al., 2014; } \\
\text { Sun et al., 2017; }\end{array}$ & $\begin{array}{l}\text { The average number of doors } \\
\text { that opened at the frontage of } \\
\text { retail shops }\end{array}$ & $\begin{array}{l}4=15-20 \text { doors per } 100 \mathrm{~m} \\
3=10-14 \text { doors per } 100 \mathrm{~m} \\
2=6-10 \text { doors per } 100 \mathrm{~m} \\
1=\text { ess than } 5 \text { doors per } 100 \mathrm{~m}\end{array}$ \\
\hline $\begin{array}{l}\text { Crossing } \\
\text { facilities }\end{array}$ & $\begin{array}{l}\text { Dijkstra and Timmermans, } \\
\text { 2002; } \\
\text { Zhu and Timmermans, 2011; } \\
\text { Guo and Loo, 2013; } \\
\text { Kim et al., 2014; Sun et al., } \\
\text { 2017; } \\
\text { Mehdizadeh et al., } 2018\end{array}$ & $\begin{array}{l}\text { The facilities at a street } \\
\text { crossing, containing traffic } \\
\text { lights and zebras }\end{array}$ & $\begin{array}{l}4=\text { Lights and zebras } \\
3=\text { Only zebras } \\
2=\text { Only lights } \\
1=\text { No pedestrian crossing facilities }\end{array}$ \\
\hline $\begin{array}{l}\text { Width of the } \\
\text { sidewalk }\end{array}$ & $\begin{array}{l}\text { Guo and Loo, 2013; } \\
\text { Kim et al., 2014; } \\
\text { Sun et al., } 2017\end{array}$ & $\begin{array}{l}\text { The actual width of the } \\
\text { pedestrian pavement can be } \\
\text { used }\end{array}$ & $\begin{array}{l}4=\text { Wider than } 3.5 \mathrm{~m} \text { (over four } \\
\text { persons in parallel) } \\
3=3.5 \text { to } 1.5 \mathrm{~m} \text { (three to four } \\
\text { persons in } \\
\text { parallel) } \\
2=\text { less than } 1.5 \mathrm{~m} \text { (two persons in } \\
\text { parallel at most) } \\
1=\text { No sidewalk }\end{array}$ \\
\hline Street greenery & $\begin{array}{l}\text { Clifton et al., 2007; } \\
\text { Kim et al., 2014; } \\
\text { Rodriguez et al., 2015; } \\
\text { Sun et al., } 2017\end{array}$ & $\begin{array}{l}\text { The plants on the street } \\
\text { containing trees and green } \\
\text { areas }\end{array}$ & $\begin{array}{l}4=\text { Trees and green areas } \\
3=\text { Only green areas } \\
2=\text { Only trees } \\
1=\text { No green areas and trees }\end{array}$ \\
\hline $\begin{array}{l}\text { The density of } \\
\text { street lamps }\end{array}$ & $\begin{array}{l}\text { Kelly et al., 2011; } \\
\text { Gase et al., 2015; } \\
\text { Moniruzzaman and Paze, } \\
2016 \text {; } \\
\text { Sun et al., } 2017\end{array}$ & $\begin{array}{l}\text { The distance between two } \\
\text { lamps in a street segment }\end{array}$ & $\begin{array}{l}4=\text { Less than } 15 \mathrm{~m} \\
3=\text { Between } 15 \text { and } 30 \mathrm{~m} \\
2=\text { More than } 30 \mathrm{~m} \\
1=\text { No lamps }\end{array}$ \\
\hline Seating & $\begin{array}{l}\text { Pushkarev and Zupan, 1975; } \\
\text { Rubenstein, 1992; }\end{array}$ & $\begin{array}{l}\text { The seats along the street in } \\
\text { which people can take a break }\end{array}$ & $\begin{array}{l}4=\text { Less than } 150 \mathrm{~m} \\
3=\operatorname{Per} 150 \mathrm{~m}\end{array}$ \\
\hline
\end{tabular}




\begin{tabular}{|c|c|c|c|}
\hline & $\begin{array}{l}\text { Marcus and Francis, 1998; } \\
\text { Shaftoe, 2008; } \\
\text { Gehl, } 2013\end{array}$ & & $\begin{array}{l}2=\text { More than } 150 \mathrm{~m} \\
1=\text { No seats }\end{array}$ \\
\hline $\begin{array}{l}\text { Shelter and } \\
\text { canopy }\end{array}$ & $\begin{array}{l}\text { Francis, 1991; } \\
\text { Rubenstein, 1992; } \\
\text { Forsyth et al., 2008; } \\
\text { Gehl, } 2013\end{array}$ & $\begin{array}{l}\text { The means of protection } \\
\text { against bad climate containing } \\
\text { arcades, canopies, and trees }\end{array}$ & $\begin{array}{l}4=\text { Along street } \\
3=\text { Less than } 150 \mathrm{~m} \\
2=\text { Per } 150 \mathrm{~m} \\
1=\text { No ones }\end{array}$ \\
\hline $\begin{array}{l}\text { Facilities for } \\
\text { disabled people }\end{array}$ & $\begin{array}{l}\text { Lynch, 1981; } \\
\text { Mahmoudi et al., } 2015\end{array}$ & $\begin{array}{l}\text { Facilities that help disabled } \\
\text { people to move, containing } \\
\text { curb ramps, railings and } \\
\text { handrails, even surfaces and } \\
\text { signage }\end{array}$ & $\begin{array}{l}4=\text { All facilities are available } \\
3=\text { Half facilities are available } \\
2=\text { Less than half facilities are } \\
\text { available } \\
1=\text { none facilities are available }\end{array}$ \\
\hline
\end{tabular}

Evaluation level: $4=$ very good, $3=\operatorname{good}, 2=$ bad, $1=$ very bad is based on the researcher's own assessment to the physical aspects and is not based on a comparison to any standards.

Source: The Authors

\section{RESEARCH METHODOLOGY}

The qualitative approach was adopted, because the specified aspects cannot be quantitative as the spatial design of sidewalks differs significantly. The varieties of users and usage differ temporally and spatially (Elsawy et al.2019). Thus, examining the physical aspects by creating a thorough set of criteria for assessing the physical conditions of livable streets can help determine its level of success for realizing a suitable livable environment. The research methodology employed observations to the physical aspects of the environment, and with the use of measurements. The research methodology did not include behavioral mapping or documenting users' behavioral patterns. The observations took place at daytime whereas observations in the evening hours and at night might yield different results due to the harsh weather conditions in the day time. The analysis is based on the measurement of urban criteria deduced from the literature in accordance with the researchers' observations; it is not based on the assessment or the opinion of the public street users. This study contains 10 aspects, each consisting of four levels (4 - very good, 3 - good, 2 - bad, 1- very bad). These aspects were applied to examine streets in the case study. The levels indicate the conditions of street. Observation is used in this study, because it is one of the most applied research techniques used in most recognized urban space studies, such as Gehl (2001), Mehta (2007), and Biddulph (2012). The immediate observations and accurate studies of the physical aspects of the studied streets were conducted by making field notes and taking photos. Data were compiled while these were conducted, and every examined aspect was recorded and classified into a table, thus creating a database for examining each aspect identified in the current work.

\section{CASE STUDY}

The Riyadh Municipality carried out an ambitious urban campaign program called "Humanizing the City" which targeted the improvement of pedestrian conditions and conversion of Riyadh to a pedestrian-friendly city. The reformation work concentrated on providing pedestrians' basic needs by expanding sidewalks and rising tree awning covers as well as plinths and outdoor seating to make a safe and convenient environment for pedestrians (Riyadh Municipality, 2008). Moreover, this initiative aimed to improve the quality of life, enhance the urban landscape, and implement universal access standards. Two representative streets developed by the Riyadh Municipality were chosen to investigate the physical characteristics of livable streets in the current study: Tahlia Street became a pedestrian attraction, while Tabuk Street did not have the same outcome after it was developed. The streets were selected based on four key reasons:

- These streets were chosen by the municipality to improve their conditions; 
- One of them had a successful experience in the development process, while the other did not, and we wanted to know the physical aspects that led to these outcomes;

- Their multifunctional aspects; and

- Ease of access for the researchers and their suitability for the study.

Tahlia Street was selected by the Riyadh Municipality to be a paradigm for the new urban commercial street in Riyadh City. The whole street length is $5 \mathrm{~km}$ east to west with a width of $60 \mathrm{~m}$, containing a broad sidewalk of $15 \mathrm{~m}$ on each side. As shown in Figure 1, the Street can be classified into four zones: (zone 1) the eastern half of Al Tahlia Street, which is a commercial urban area where most of the coffee shops and restaurants are located; (zone 2) the middle section passes through the urban center of Riyadh where there is a concentration of high-rise office blocks; (zone 3) the mid-west section is a commercial area with construction and furniture stores; and (zone 4) is the western end of the street, which is an expensive residential area (Almahmood et al., 2018).

Zone 1 was chosen, and its physical characteristics were studied because it almost resembled Tabuk Street in length and usage. The Street has become a main attraction for a wide range of visitors who come to the Street to do many things like walk, eat, meet friends, and go shopping, and this was achieved by balancing traffic and pedestrian movements in addition to encouraging restaurants and coffee shops to open along the Street and use the broad sidewalk for outdoor seating (Bin Ayyaf, 2015).
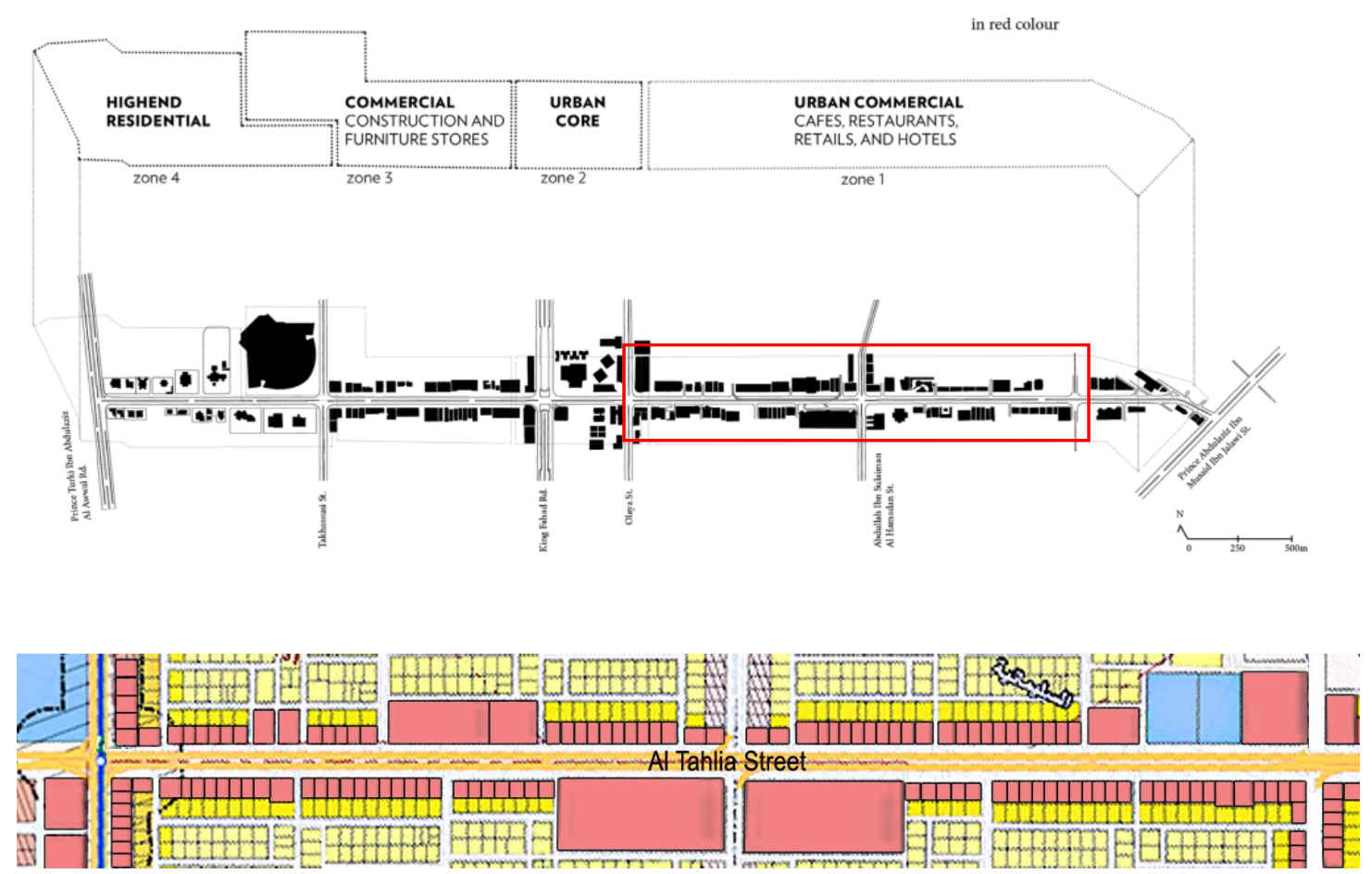

Zone 1 with land use 


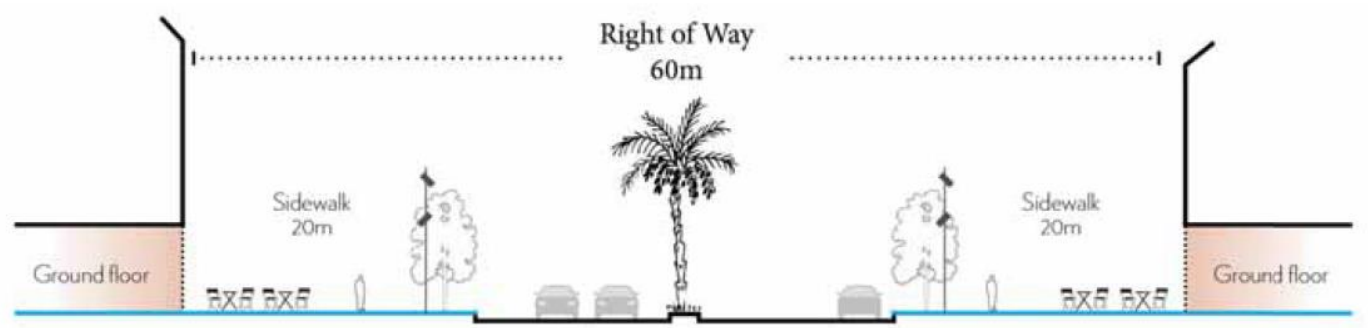

Figure (1). Al Tahlia Street with four zones Source: Almahmood et al, 2018.

Tabuk Street is located in the northern part of Riyadh City with a length of about 1 $\mathrm{km}$ and a width of approximately $36 \mathrm{~m}$. In Riyadh, the city streets in the planned areas are classified as commercial streets if they are equal to or over 30 meters. Most of the plots of land on the Street have a width and depth of $30 \mathrm{~m}$ and 30, respectively. As shown in Figure 2, Tabuk Street is not a motorway, which gives it an added advantage in terms of the possibility of development and improvement without disrupting traffic. Furthermore, Tabuk Street is characterized as one of the streets that have been developed by the Riyadh Municipality to create a comfortable environment for pedestrians.

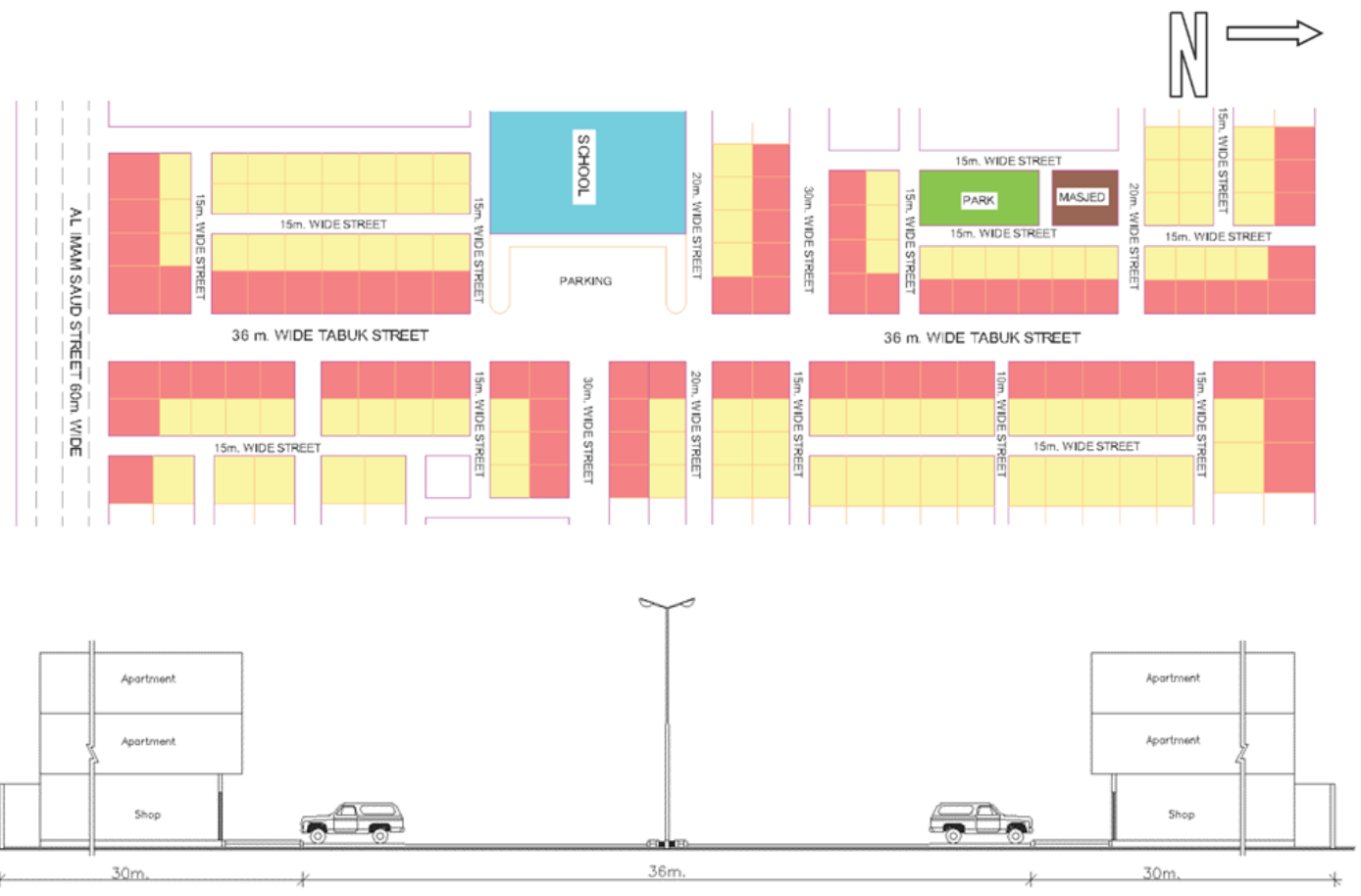

Figure (2). Tabuk Street with land use Source: Alskait,2019.

\section{ANALYSIS OF TAHLIA STREET CASE STUDY}

The physical characteristics of the built environment along Tahlia Street were measured during the observational valuation by the researchers. Table 2 and Figure 3 summarize the descriptive analysis of the physical aspects of Tahlia Street. The street segment length is good, ranging between $100 \mathrm{~m}$ and $200 \mathrm{~m}$. There are some street segments that are over $300 \mathrm{~m}$, while there are some that are less than $100 \mathrm{~m}$. The retail shops found on the street facade are all very good, because land use has been allotted for commercial purposes. In fact, the Street is classified as a commercial street and even 
the ground floors of all buildings are used for commercial activities. The average number of doors is good at 11 doors per $100 \mathrm{~m}$. There are some buildings that use the ground floor for one activity and therefore use just one door. The crossing facilities are very good, but they need continuous maintenance. The width of the sidewalk is also very good at approximately $15 \mathrm{~m}$ in width.

The sidewalk is enough to accommodate over four persons in parallel. However, street greeneries are below expectations, because the Street contains some trees that do not provide shaded areas. Moreover, green areas are not available, and most of the surfaces are covered with concrete tiles. The density of street lamps is good, as the distance between two lamps is $20 \mathrm{~m}$. Generally, plinths are distributed along the Street without pergolas, while seats are only available in front of the restaurants. The shelter and canopy are very bad, because the Street has no means of protection against bad weather, except some areas with trees that do not even provide shade. Finally, the facilities for disabled people are not up to standard, as there are few ramps for the disabled. Some shops also have stairs in front, which impede the movement of the handicapped.

Table (2). Evaluating the livability of Tahlia Street

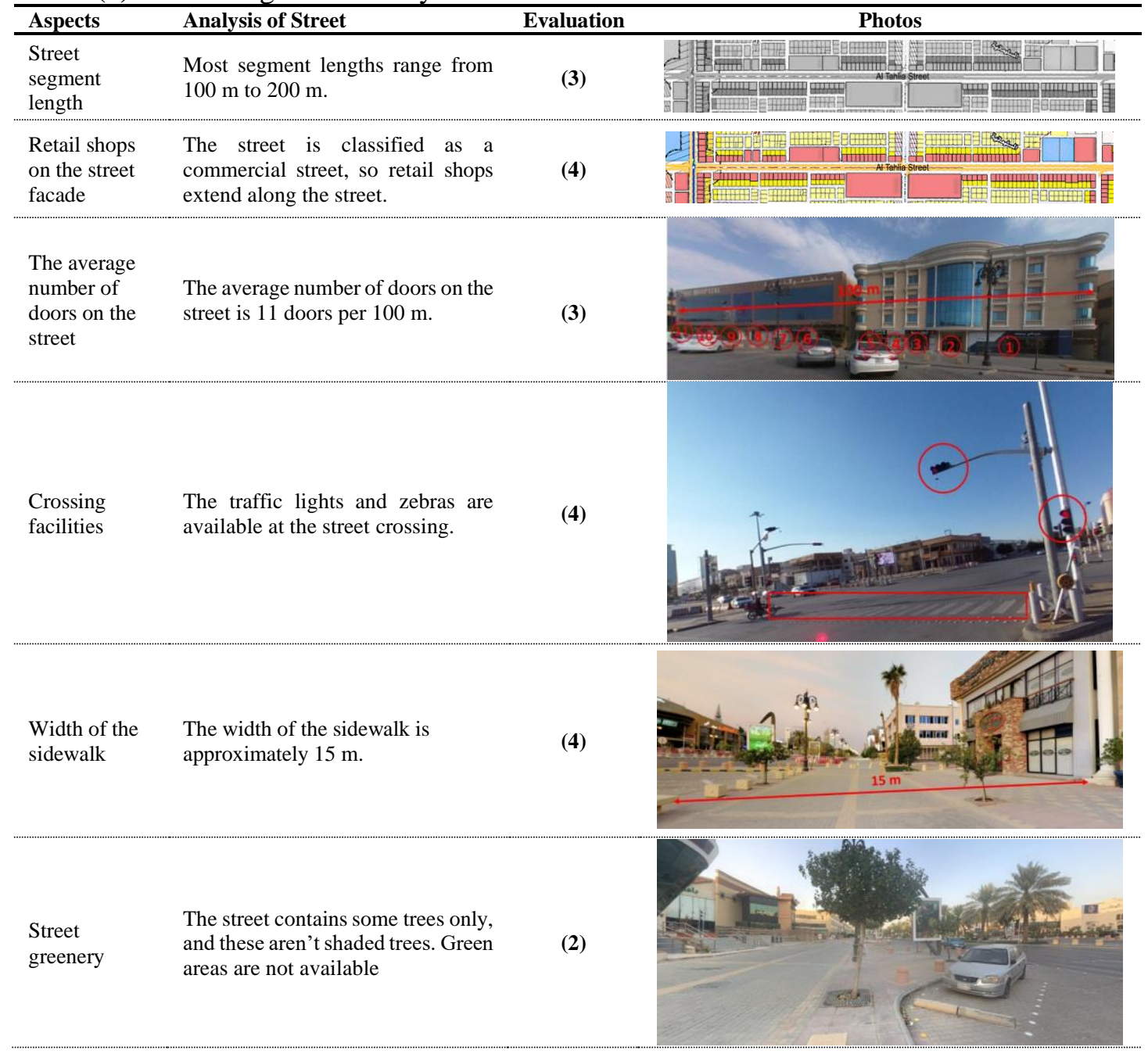




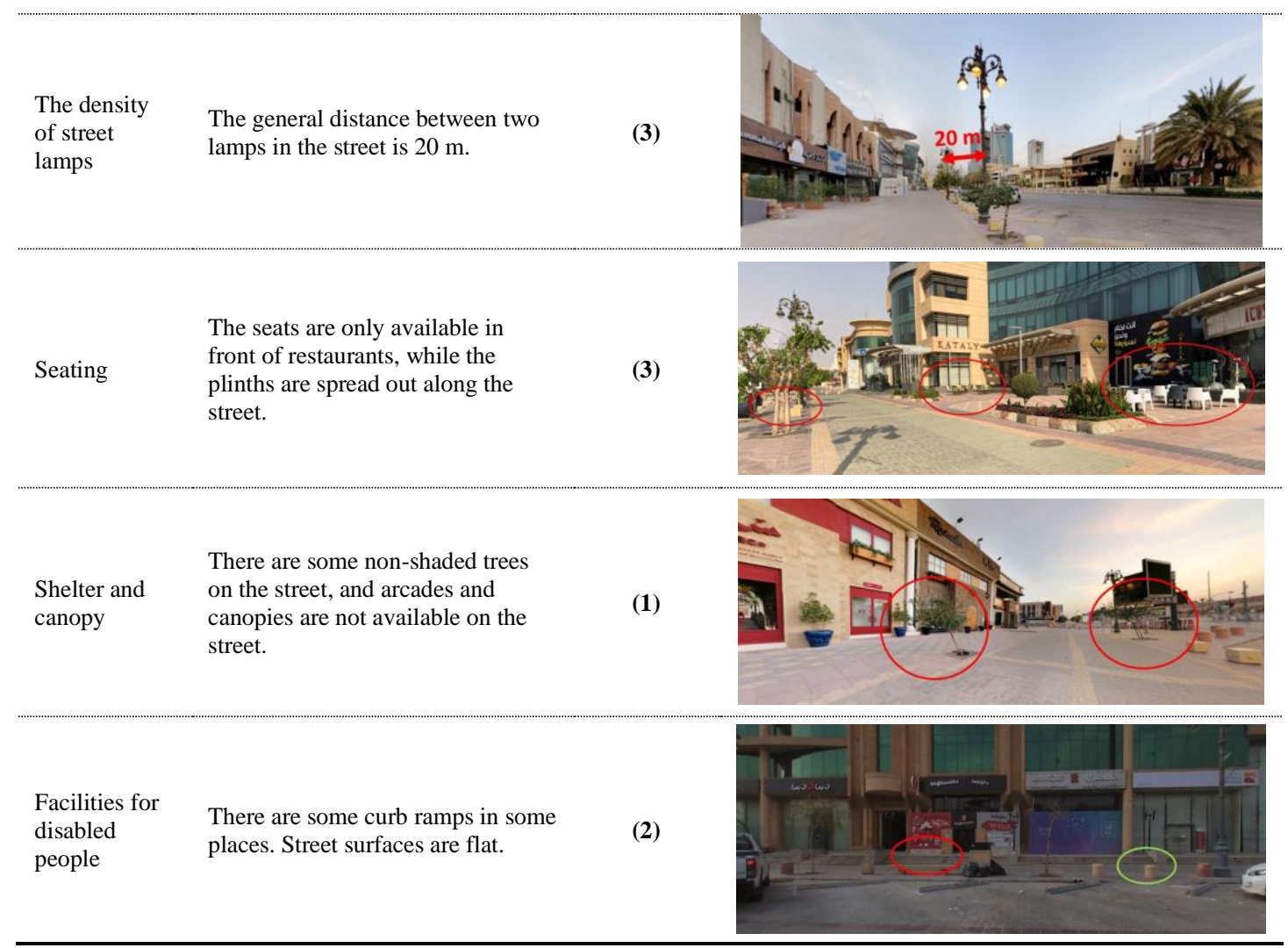

Evaluation level: $4=$ very good, $3=\operatorname{good}, 2=$ bad, $1=$ very bad is based on the researcher's own assessment to the physical aspects and is not based on a comparison to any standards.

Source: The Authors

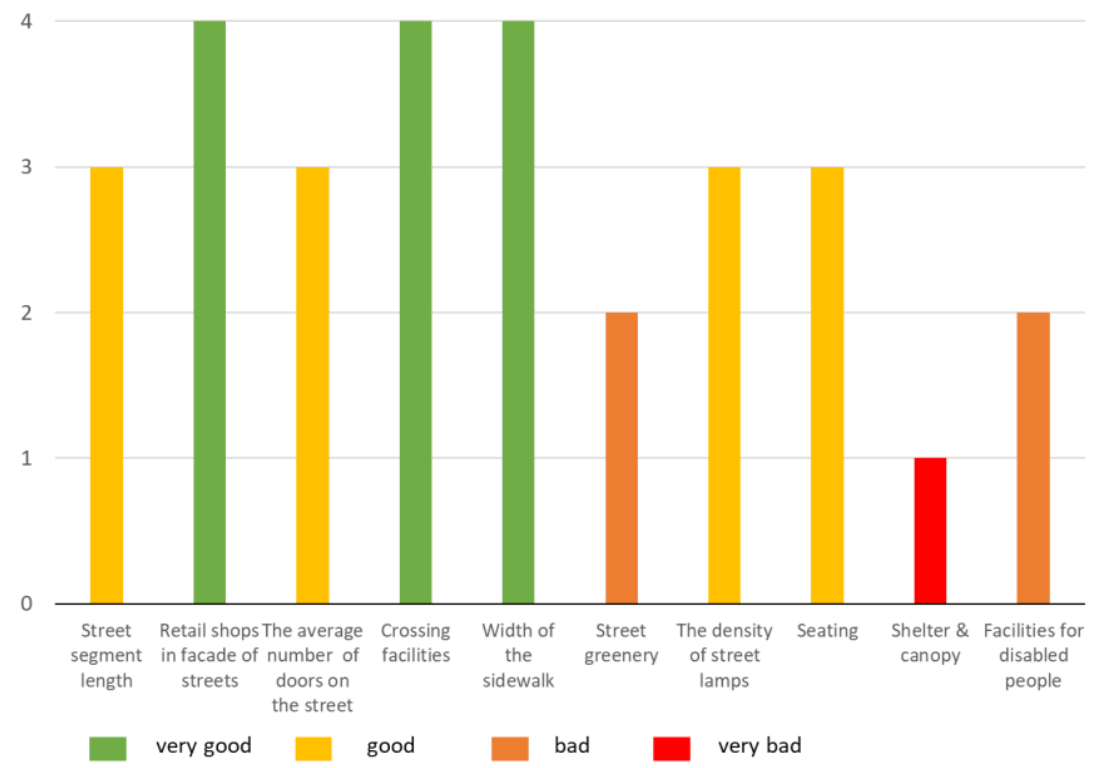

Figure (3). Evaluating the livability of Al Tahlia Street

Source: The Authors

\section{EVALUATING THE LIVABILITY OF TABUK STREET}

For comparison, the physical characteristics of the built environment along Tabuk Street were measured during the observational valuation by the researchers. Table 3 and Figure 4 summarize the descriptive analysis of the physical aspects along Tabuk Street. The street segment length is good ranging between $100 \mathrm{~m}$ and $200 \mathrm{~m}$. However, 
there are some street segments that are less than $100 \mathrm{~m}$. The retail shops found on the facade of the Street are very good, as land use is planned for commercial purposes. It is classified as a commercial street, and the ground floors of most buildings are used for commercial activities. There are some buildings that use the ground floor for just one activity and therefore use only a single door. The crossing facilities are very bad, because the traffic lights and pedestrian lines are not available at the street crossing.

The width of the sidewalk is very good at approximately $4 \mathrm{~m}$. The sidewalk is enough to accommodate over four persons in parallel. The street greenery is very bad, because there are no trees found. Moreover, green areas are not available, and most of the street surfaces are covered with concrete tiles. The density of street lamps is very good, as distance between two lamps is $10 \mathrm{~m}$ on average. The seats are not available, and plinths spread out along the length of the Street. In addition, shelter and canopies are very bad, because Tabuk Street has no means of protection against bad weather. There are no arcades, canopies, and shaded trees. Finally, the facilities for disabled people are very bad, as there are no any ramps, railings, signage, and handrails that can help disabled people move about.

Table (3). Evaluating the livability of Tabuk Street

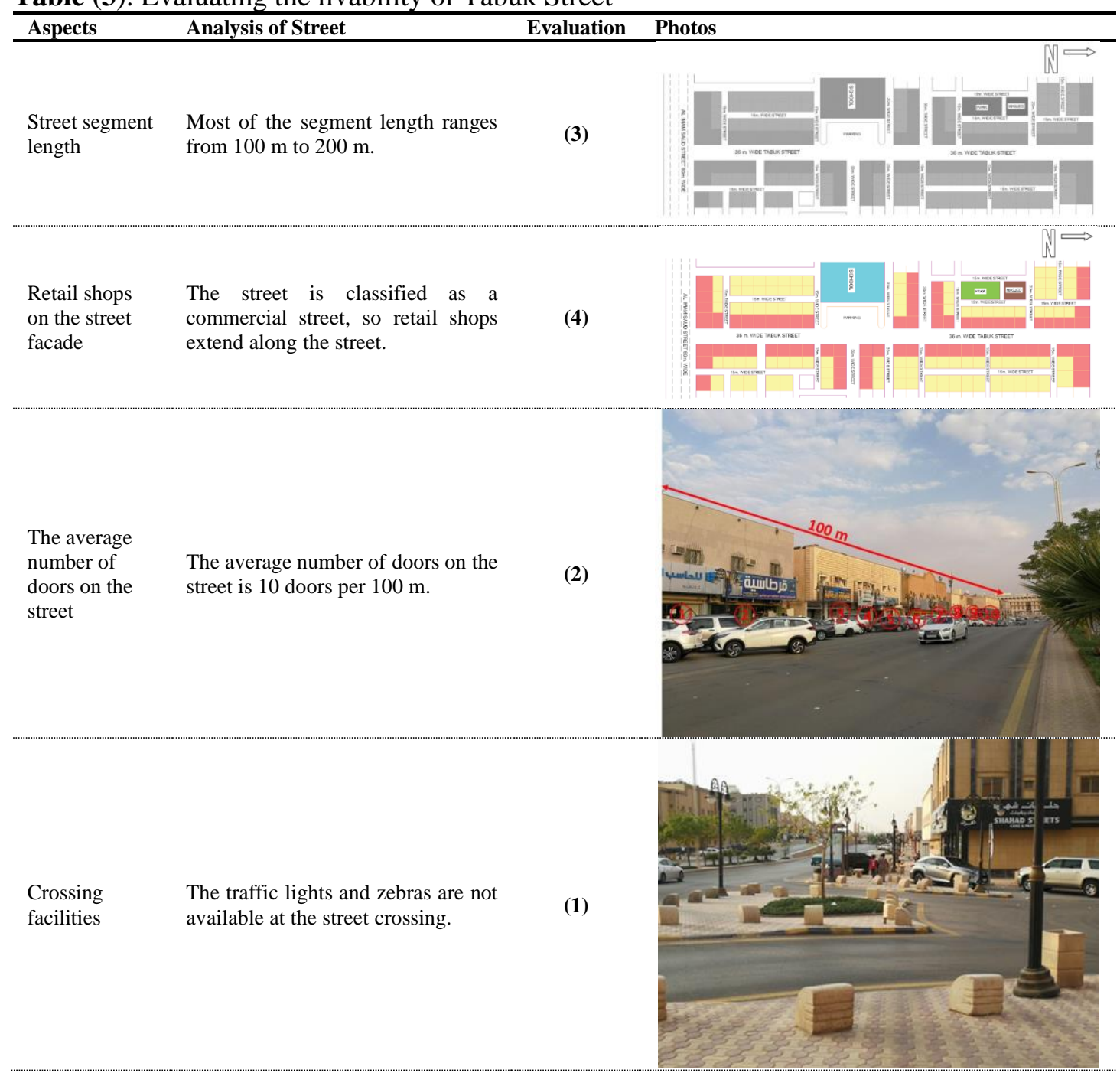


Width of the sidewalk

The width of the sidewalk is approximately $4 \mathrm{~m}$.

(4)

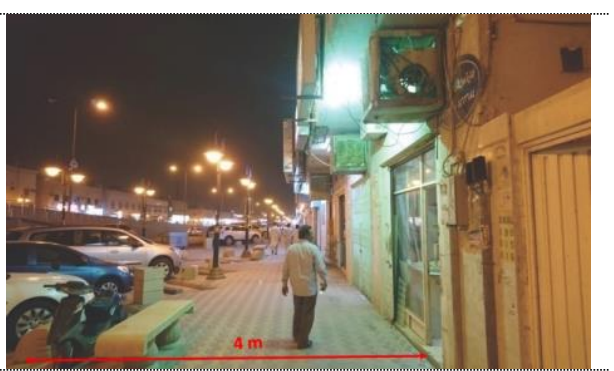

Street

There are no trees or green areas on

greeneries the street.

(1)

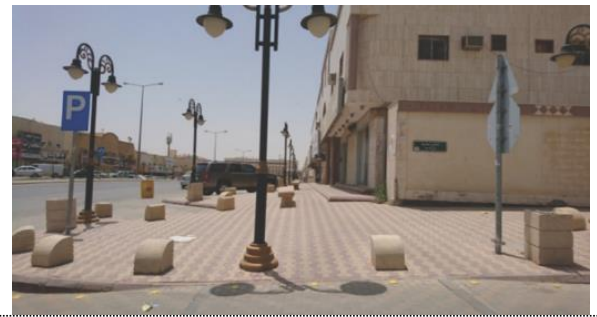

The density of

The distance between two lamps in street lamps

the street is $10 \mathrm{~m}$.

(4)

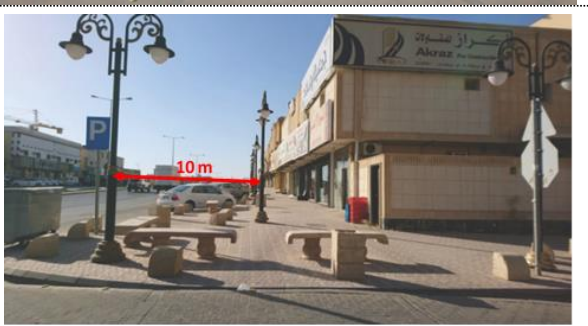

The seats are not available on the street, and plinths spread out along the street.

(2)

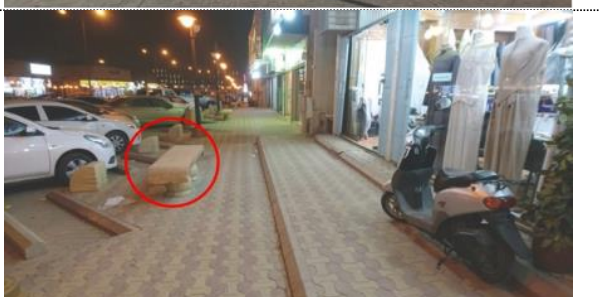

Shelter and canopy
There are no shaded trees, arcades, and canopies on the street.
(1)
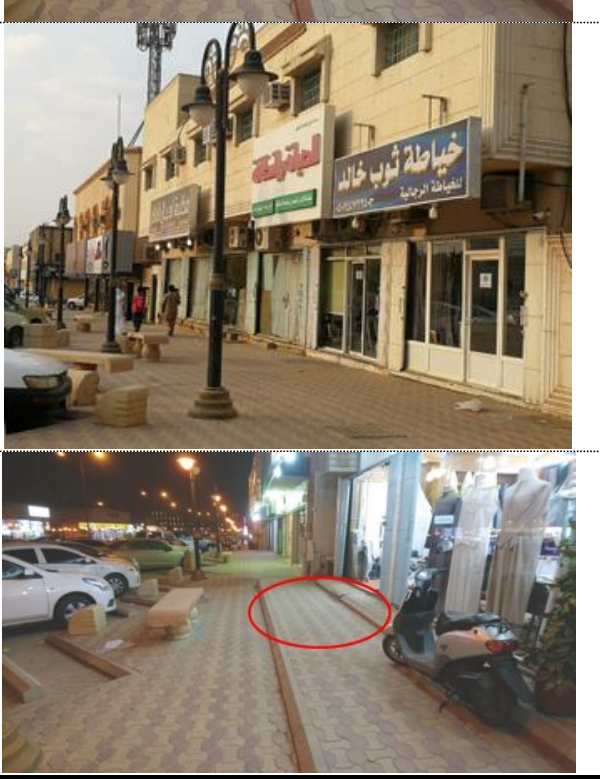

(1)
Facilities for disabled people
Facilities for disabled people are not available on the street.

Evaluation level: 4 = very good, 3 = good, 2 = bad, $1=$ very bad is based on the researcher's own assessment to the physical aspects and is not based on a comparison to any standards.

Source: The Authors 


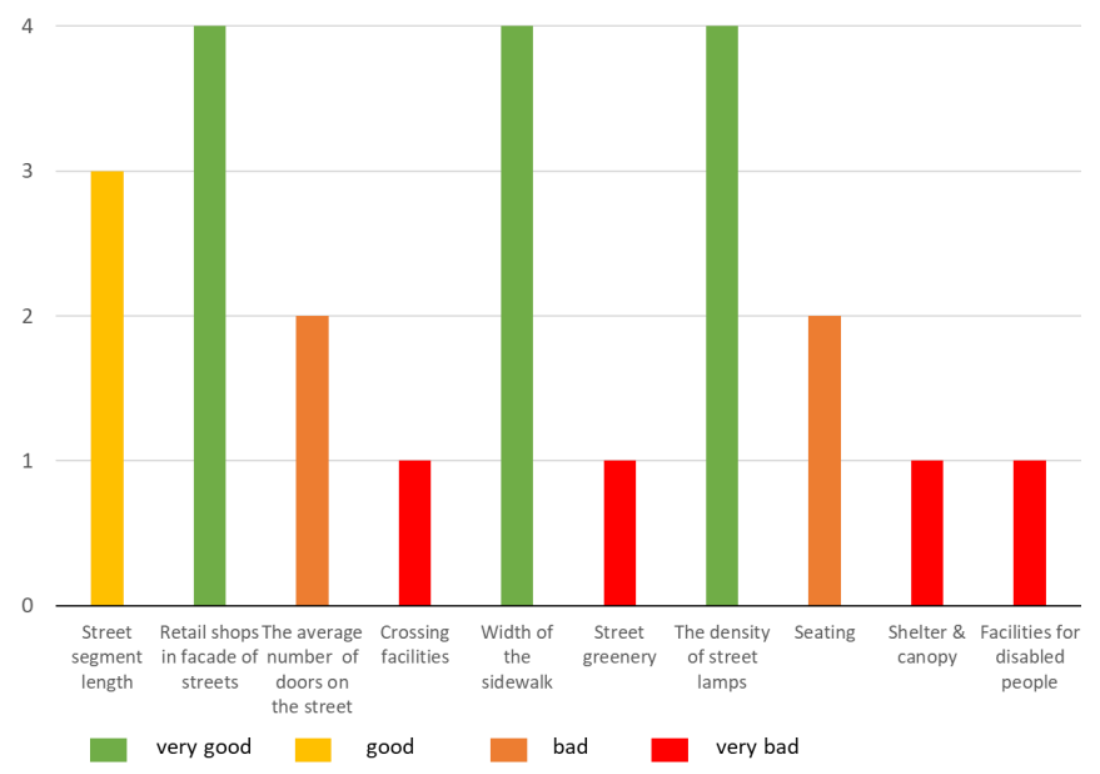

Figure (4). Evaluating the livability of Tabuk Street Source: The Authors

\section{CONCLUSION}

This paper evaluated the physical characteristics of two streets in Riyadh within the framework of the concept of livable streets. There are many urban aspects that enhance the livability of streets, such as the length of the street, the type of commercial activities, crossing facilities, width of the sidewalk, and facilities for the disabled. Moreover, livable streets are affected by the availability of street greeneries, sufficient lighting, shaded areas, and seating areas. The results showed variations in the physical characteristics of the streets, which affect their livability. Tahlia Street is more lively compared to Tabuk Street, because it contains multiple urban elements, such as the diversity of commercial activities, sidewalks, and pedestrian facilities. However, both streets lack facilities for the disabled, street greeneries, and adequate seating. These results can thus help decision-makers and local municipalities in developing the urban environments for pedestrian streets in Riyadh within the framework of humanizing cities.

As a recommendation, the following aspects also need to be considered:

1. Developing a strategy to improve the urban environment for pedestrian streets in Riyadh by enhancing community participation and analyzing the current situation;

2. Diversifying commercial activities in pedestrian streets and linking them to a public transport network;

3. Improving urban spaces and providing street furniture elements, such as smart lighting, seats, green areas, and ramps for the disabled, which can help increase vitality;

4. Providing pedestrian protection from vehicles in the form of traffic lights, pedestrian lines, and speed reducers;

5. Providing means of protection against bad weather, including arcades, canopies, and trees for Al Tahlia Street and Tabuk Street; 
6. Improving the urban environment for pedestrians in Tabuk Street and providing facilities for the disabled, street greeneries, and adequate seating;

7. Increasing the percentage of green spaces along the pedestrian street paths to improve climatic conditions; and

8. Conducting assessments based on the street users' and pedestrians' evaluation in future studies to compare against the findings of this research.

\section{References}

Ahmed, N., Elshater, A., \& Afifi, S. (2019, February). The Community Participation in the Design Process of Livable Streets. In International Conference on Innovations and Interdisciplinary Solutions for Underserved Areas (pp. 144-157). Springer, Cham.

Alzamil, W. (2016). Evaluation of Affordable Housing and Subsidy Programs in Saudi Arabia. Saarbrücken: LAP LAMBERT Academic Publishing.

Amin, A. (2008). Collective culture and urban public space. Journal of City.

Appleyard, D. (1981) Livable Streets. Berkeley, CA: University of California Press.

Appleyard, D., \& Lintell, Mark. (1972). The environmental quality of city streets: The residents' viewpoint. Journal of the American Institute of Planners.

Appleyard, B. (2017). The meaning of livable streets to schoolchildren: An image mapping study of the effects of traffic on children's cognitive development of spatial knowledge. Journal of Transport \& Health.

Appleyard, B., \& Douglass, P. (2017). 2188 - Livable Streets 2.0 Street Conflict, Power, and Promise for Livability, Health, and Humanity in the Age of Driverless Cars: An International Perspective. Journal of Transport \& Health. doi:doi.org/10.1016/j.jth.2017.05.273

Appleyard, D. (1980). Livable Streets: Protected Neighborhoods? The American Academy of Political and Social Science. doi:doi.org/10.1177/000271628045100111

Alfonzo, M., Guo, Z., Lin, L., Dayaks. (2014). Walking, obesity and urban design in Chinese neighborhoods. Am. J. Prev. Med.

Al-Mosaind, M. (2018). Applying complete streets concept in Riyadh, Saudi Arabia: opportunities and challenges. Urban, Planning and Transport Research.

Al-Hathloul, S. (2017). Riyadh development plans in the past fifty years (1967-2016). Current Urban Studies.

Almahmood, M., Schulze, O., Carstensen, T. A., \& Jørgensen, G. (2018). The Sidewalk as a Contested Space: Women's Negotiation of Socio-Spatial Processes of Exclusion in Public Urban Space in Saudi Arabia; The Case of Al Tahlia Street. Planning Practice \& Research.

Alskait, K. (2019). Evaluation of the Urban Planning \& Design of Tabuk Street, Riyadh, Saudi Arabia, In Light of Form-Based Code Principles. Journal Architecture \& Planning, vol. 31(1), pp.27-55.

Bandar Abad, A., \& Shahcheraghi, A. (2012). Livable street in urban environment: an adaptive design approach. Advances in Environmental Biology.

Biddulph, M. (2012) Radical streets? The impact of innovative street designs on liveability and activity in residential areas. Urban Design International.

Bin Ayyaf, A. (2015). Enhancing the Human Dimension in Municipal Work, Riyadh as a Case. Riyadh: Tarah International.

Borgers, A.W.J., Timmermans ,H.J.P.( 2015). Modeling pedestrians' shopping behavior in downtown areas. In: Ferreira Jr.J., Good speed, R. (Eds.), CUPUM $2015-14^{\text {th }}$ International Conference on Computers in Urban Planning and Urban Management. Cambridge, USA July.

Bosselmann, P., Macdonald, E., \& Kronemeyer, T. (1999). Livable streets revisited. Journal of the American Planning Association. 
Clifton, K.J., Smith, A.D.L., Rodriguez, D. (2007). The development and testing of anaudit for the pedestrian environment. Landsc. Urban Plan.

Davis, M. (1990) City of Quartz: Excavating the Future in Los Angeles. London.

Dijkstra, J., Timmermans, H.J.P., (2002). Towards a multi-agent model for visualizing simulated user behavior to support the assessment of design performance. Autom.Constr.

Dumbaugh, E. and Gattis, J. (2005) Safe streets, livable streets. Journal of the American Planning Association.

Elsawy, A. A., Ayad, H. M., \& Saadallah, D. (2019). Assessing livability of residential streetsCase study: El-Attarin, Alexandria, Egypt. Alexandria Engineering Journal.

Francis, M. (1991). The making of democratic streets. In A. V. Moudon (Ed.), Public streets for public use. New York: Columbia University Press.

Forsyth, A., Hearst, M., Oakes, J. M., \& Schmitz, K. H. (2008). Design and destinations: Factors influencing walking and total physical activity. Urban Studies.

Gase, L.N., Barragan, N.C., Simon, P.A., Jackson, R.J., Kuo, T., 2015. Public awareness of and support for infrastructure changes designed to increase walking and biking in Los Angeles County. Prev. Med.

Gehl, J. (2013). Cities for people. Island Press.

Gehl, J. (2001) Life Between Buildings: Using Public Space. Copenhagen, Denmark: Danish Architectural Press.

Guo, Z., Loo,B.P.Y.(2013).Pedestrian environment and route choice :evidence from new York City and Hong Kong. Transp Geogr.

Hedman, R., \& Jaszewski, A. (1984). Fundamentals of Urban Design. Washington, D.C: APA Planners Press.

Herrman, T., \& Lewis, R. (2017). What is Livability? Eugene: sustainable cities initiative SCI.

Jacobs, J. (1961) The Death and Life of Great American Cities. New York: Random House Digital, Inc.

Jacobs, A., \& Appleyard, D. (1987). Toward an Urban Design Manifesto. Journal of the American Planning Association.

Kelly, C.E., Tight, M.R., Hodgson, F.C., Page, M.W., 2011. Acomparison of three methods for assessing the walkability of the pedestrian environment. Transport Geography.

Kim, S., Park, S., Lee, J.S. (2014). Meso-or micro - scale? Environmental factors influencing pedestrian satisfaction. Transp. Res. Part D: Transp. Environ.

Krier, R. (1979). Urban space. London: Academy Editions.

Low, S., \& Smith, N. (Eds.). (2006). The politic of public space. New York: Routledge.

Lynch, K. (1981). A theory of good city form. Cambridge: MIT Press.

Kurose, S., Deguchi, A., Zhao, S., (2009). Comparative study of pedestrian behavior in central shopping areas of east Asian cities. In: Pedestrian Behavior: Models, Data Collection and Applications. Emerald Group Publishing Limited, Bingley.

Madanipour, A., Cars, G. and Allen, J. (1998) Social Exclusion in European Cities: Processes, Experiences, and Responses. London: Jessica Kingsley.

Mahmoudi, M., Ahmad, F., \& Abbasi, B. (2015). Livable streets: The effects of physical przoblems on the quality and livability of Kuala Lumpur streets. Cities.

Marcus, C. C., \& Francis, C. (Eds.). (1998). People places: Design guideline for urban open spaces (2nd ed). New York: John Wiley \& Sons Inc.

Mehta, V. (2007) Lively streets: Determining environmental characteristics to support social behavior. Journal of planning education and research.

Mesbahul Tariq, M. (2007). Livable streetscape: Creating a pedestrian network in the town of Morden, Monitoba. (Master Thesis), University of Manitoba, Winnipeg, Canada.

Mehdizadeh, M., Nordfjaern, T., Mamdoohi, A. (2018). The role of socio-economic, built environment and psychological factors in parental mode choice for their children in an Iranian setting. Transportation.

Mehta, V. (2007) Lively streets: Determining environmental characteristics to support social behavior. Journal of planning education and research. 
Mitchell, D. (2003). The right to the city: Social Justice and the fight for public space. New York: Guilford.

Moniruzzaman, M., Paez, A. (2016). An investigation of the attributes of walkable environments from the perspective of seniors in Montreal. Transp. Geogr.

Quality of Life Program. (2017). Quality of Life Program Document. Riyadh: Quality of Life Program.

Retrieve from: https://vision2030.gov.sa/sites/default/files/attachments/QoL\%20English_0.pdf Riyadh Municipality. (2008). Riyadh City: Pedestrian Friendly City. Riyadh: Riyadh Municipality. Retrieve from: https://www.alriyadh.gov.sa/en/mayors/Pages/Prince-AbdulAziz-Bin-Mohammed-Bin-Ayyaf.aspx

Riyadh Municipality. (2015). Riyadh City Walkways. Available at http://park.alriyadh.gov.sa/M_Root.aspx (accessed 17 August 2015)

Rodriguez, A.D., Merlin, L., Prato, G.C., Conway, L.T., Cohen, D., Elder, P.J., Evenson, R.K., McKenzie, L.T., Pickrel, L.J., Mortenson, V.S. (2015). Influence of the built environment on pedestrian route choices of adolescent girls. Environ. Behav.

Rubenstein, H. M. (1992). Pedestrian malls, streetscapes, and urban spaces. New York, NY: John Wiley \& Sons Inc.

Royal Commission for Riyadh City. (2014). The comprehensive strategic plan for the city of Riyadh 1450 AH. Riyadh: Royal Commission for Riyadh City. Retrieve from: https://www.rcrc.gov.sa/wp-content/uploads/2019/10/publication.pdf

Royal Commission for Riyadh City. (2018). Lands available for development in Riyadh until 1450 AH (Map). Riyadh: f for Riyadh City.

Safdie, M. (2018). The city after the automobile: an architect's vision. Routledge.

Sauter, D. and Huettenmoser, M. (2008) Liveable streets and social inclusion. Urban Design International.

Shaftoe, H. (2008). Convivial urban spaces: Creating effective public places. Retrieved from http://site.ebrary.com/lib/malaya/docPrint.action.

Soja, E. (1989) Postmodern Geographies: Reassertion of Space in Critical Social Theory. London: Verso.

Speiregen, A. P. D. (1965). Urban design: The architecture of towns and cities. United States of America: McGraw-Hill Book Company.

Sun, G., Webster, C., Chiaradia, A. (2017). Objective assessment of station approach routes: development and reliability of an audit for walking environments around metro stations in China. J. Transp. Health.

Tilaki, M. J. M., Abdullah, A., Bahauddin, A., \& Hedayati Marzbali, M. (2014). The necessity of increasing livability for george town world heritage site: An analytical review. Modern Applied Science.

Vuchic, V. (2017). Transportation for livable cities. Routledge: New York.

Whitney, R. A., Hess, P. M., \& Sarmiento-Casas, C. (2020). Livable Streets and Global Competitiveness: A Survey of Mexico City. Journal of Planning Education and Research.

Zhu, W., Timmermans, H.J.P., (2011). Modeling pedestrian shopping behavior using principles of bounded rationality: model comparison and validation. J. Geogr. Syst. 